\title{
Mulemba
}

Revista Angolana de Ciências Sociais

\section{The conquest of Ambriz: Colonial expansion and imperial competition in Central Africa}

A conquista do Ambriz: a expansão colonial e competição imperial na África

Central

Roquinaldo Ferreira

\section{OpenEdition}

Journals

Electronic version

URL: http://journals.openedition.org/mulemba/439

DOI: $10.4000 /$ mulemba.439

ISSN: 2520-0305

Publisher

Edições Pedago

Printed version

Date of publication: 1 May 2015

Number of pages: 221-242

ISSN: 2182-6471

\section{Electronic reference}

Roquinaldo Ferreira, "The conquest of Ambriz: Colonial expansion and imperial competition in Central Africa", Mulemba [Online], 5 (9) | 2015, Online since 28 November 2016, connection on 26 January 2021. URL: http://journals.openedition.org/mulemba/439 ; DOI: https://doi.org/10.4000/mulemba.439

This text was automatically generated on 26 January 2021.

Tous droits réservés 


\title{
The conquest of Ambriz: Colonial expansion and imperial competition in Central Africa
}

\author{
A conquista do Ambriz: a expansão colonial e competição imperial na África \\ Central
}

Roquinaldo Ferreira

\section{EDITOR'S NOTE}

Recepção do manuscrito: 24/11/2014

Aceite para publicação: 20/04/2015

\section{AUTHOR'S NOTE}

O presente texto integrou um conjunto de quatro conferências que o historiador brasileiro Roquinaldo Ferreira, na sua qualidade de professor visitante da FCS-UAN, orientou em Luanda nos dias 2, 4, 5 e 6 de Dezembro de 2013, sob os auspícios do Departamento de História da FCS-UAN.

In 1859, Governor of Angola José Rodrigues Coelho do Amaral held a gala dinner at the governor palace in Luanda to celebrate the birthday of queen of Portugal Estefania that brought together the crème de la crème of the Luanda elite. ${ }^{1}$ Six foreign consuls were on attendance, as well as the highest echelon of the colonial administration and of Luanda's society, including a controversial Brazilian named Francisco Antonio Flores, who had played a critical role in the slave trade to first Brazil and then to Cuba. Flores had also invested in legal economics projects, contributing to shift the Angolan economy away from the slave trade, had skillfully deployed cultural diplomacy to persuade African rulers to support the extension of Portuguese colonial control to 
Ambriz and Cabinda, and had masterminded and funded the Portuguese expedition that led to the extension of colonial control to Ambriz, a region long claimed by the Portuguese but disputed by the British, American and French powers.

Flores was one of the most high profiles denizens of Luanda. In 1853, the Brazilian national was said to have received interim Angolan governor Antonio Ricardo Graça to «eat and drink» at his house. ${ }^{2}$ In the 1860s, he received the traveler Richard Burton, who dined at his house and remarked that the Brazilian had also hosted Henry Huntley, a British diplomat then serving as the commissioner on the comissão mixta (BURTON 1876). In 1862, he received honorable mention at the London world fair for presenting «interesting samples of cooper» (Annaes do Conselho Ultramarino 1867: 20).

Also in attendance was Flores' nemesis, George Jackson, a British diplomat who had recently retired from his position as British representative in the Comissão Mixta after almost fifteen years in Luanda. The British had arrived in Luanda in 1845, already at sixty years old man, after having lived as a diplomat in several European capitals and in the United States. He had deeply knowledge of the slave trade, having already held the position of judge on mixed commissions around the Atlantic: «in 1828 he was named commissary judge of the mixed commission court at Sierra Leone [...] from 1832 to 1859, he was chief commissioner - under the convention for the abolition of the African slave trade - first, at Rio de Janeiro, until 1841, whence he was transferred to Surinam, and afterwards, from 1845, at St. Paul de Loanda» (JACKSON ed., 1872: 2-4).

4 The two men's bitter relationship was a microcosm of the larger struggle to end the slave trade and of the imperial disputes between the Portuguese and the British over territorial sovereignty in Ambriz and Cabinda. Scholars have stated that «in the middle decades of the century the mixed commissions functioned more like arms of British imperial authority than sites for diffusing humanitarian sentiment» (BENTON 2011: 369). In a way, however, Jackson's power in Luanda was not reflective of the overall British influence in the city since the arrival of the first British diplomats in Luanda in the 1840s. Another British diplomat, George Brand, had to wait almost one year before Portuguese authorities allowed him to serve on the mixed the commission. ${ }^{3}$ Edmond Gabriel, another British representative in Luanda, once declared: «In my isolation position, I seldom hear of anything until long after it has happened». ${ }^{4}$

In contrast, Jackson wielded incomparable influence in Luanda, «forcefully requesting explanations about policies [from governors of Angola]». ${ }^{5}$ To that end, he deployed not only British considerable military and political power but also a network of local spies that supplied him with intelligence about the slave trade and Portuguese colonial projects: «Sir Jorge Jackson has at his disposal many means of espionage to monitor this government's steps on the issue of Cabinda and Ambriz, and I have been informed that he received an annual sum of three thousand pounds to maintain this espionage [network]». ${ }^{6}$

6 However, while British pressure had forced Flores into exile several times, the British had been unable to completely prevent the Brazilian from developing tight connections with the Luanda elite and from becoming a key partner to Portuguese colonial plans. Unsurprisingly, the British diplomat did not react well when he spotted the Brazilian businessman in the gala dinner. As Governor of Angola José Rodrigues Coelho do Amaral pointed out, Jackson «walked up to the general secretary [Angola] and asked who was that individual, as though he did not know him perfectly!, and once he heard his name, he left with a big scene». ${ }^{7}$ 


\section{Early life in Luanda and business}

7 Who exactly was Francisco Antonio Flores? The Brazilian had first gone to Angola in the early 1840s. In 1843 , official records showed him signing a bond attesting that a ship that had departed from Luanda in ballast would not be involved in the slave trade. ${ }^{8}$ There is no doubt that by then he was already involved in the slave trade. In 1846 , a Portuguese consul in Rio de Janeiro informed authorities in Luanda that the ship that Flores handled in Angola (General Rego) had left Rio for Angola. ${ }^{9}$ As a former slave dealer would say several years later, "the brigue General Rego belonged to the slave trading commercial house of Amaral e Bastos»..$^{10}$ Flores also had ties to the famed Manoel Pinto da Fonseca, a Rio de Janeiro slave dealer who was the owner of a ship that used by Flores to conduct trade between Luanda and other regions of coastal Angola (KARASCH 1967: 36).

8 Flores' early career in Angola established a remarkably consistent pattern of business operation and social strategy. He invested not only in the slave trade but also in legitimate activities, requesting licenses to import cigars (charutos), tobacco, sugar, manioc, and Brazilian rum. ${ }^{11}$ While based in Luanda, he soon began investing in Ambriz and Cabinda, establishing ties with African rulers that would later help him play an important role as a diplomat on behalf of the Luanda administration. In his early years in Luanda, he traveled several times to Ambriz and Cabinda. In 1846, for example, he received a passport to travel to Cabinda, being then described as a twenty nine years old Brazilian who had been born in Rio Grande [do Sul]. ${ }^{12}$

9 A few years later, he traveled (with a mixed-race servant) to Ambriz, soon to become a focal point for his business activities. ${ }^{13}$

10 He quickly integrated in Luanda's trading community, partnering with Francisco Teixeira de Miranda, a Brazilian national who had arrived to Luanda in the late 1830s, also as a representative of a Rio de Janeiro's slave trade house. In 1842, after six years living in the city, Miranda was described as a merchant who did «all quality of commerce in partnership with a trading house from Rio de Janeiro and that he was more a volante than a permanent merchant». ${ }^{14}$ Several months later, authorities stated that Miranda's stay in the city "was of great utility due not only to property taxes that he paid on his buildings but also due to the amount of money he paid in custom duties». As the governor pointed out, Miranda had also been a high-profile benefactor to the city. ${ }^{15}$

11 Miranda introduced Flores to several Luanda merchants, including Arsenio Pompílio Pompeu de Carpo and Ana Joaquina dos Santos Silva, perhaps the largest slave dealers in town in the 1840s. In 1843, the four partnered to establish a steam boat company meant to export legal products from Angola to Portugal. To obtain support from the Luanda administration, then seeking to create sources of revenues alternative to shipments of slaves from Luanda, they argued that the company would foster the transition from the slave trade to the licit trade in Angola. ${ }^{16}$ Later, however, the project collapsed amid accusations that it was a hoax and that the merchants planned to use the steam boat in the slave trade to Brazil. ${ }^{17}$

By the 1850s, the Brazilian had become perhaps the most important philanthropists in Luanda. In 1855, for example, he donated four hundred thousand réis to the Santa Casa de Misericórdia of Luanda. ${ }^{18}$ In 1856, he donated food supplies to Luanda regular troop, including «a portion of bottles of good champagne, cans of preserved fruit and sweets for 
officers to eat as desert in their dinners». ${ }^{19}$ In 1857, through his agent Augusto Garrido, he helped the Luanda administration to procure food supplies to Luanda. ${ }^{20}$ As pointed out earlier, his trading house was involved in fundraising to assist people stricken with yellow fever in Lisbon. ${ }^{21}$

By then, Flores' investments were backed by the Luanda administration or reflected the geopolitical interests of the administration. In 1858, when Flores created a steamboat company, authorities indicated the name of Joaquim Correia da Conceição to become the Benguela representative of the company. ${ }^{22}$ In March 1856, after the Portuguese occupation of Ambriz, he successfully requested rights to maintain three factories in northern Angola at Ambrizete, Mangue and Porto da Lenha. ${ }^{23}$ Among the many goods he sold in these establishments, were gunpowder and weapons. ${ }^{24}$ In addition, he would regularly receive commodities from England, which were later distributed to his establishments along the Angolan coast, receiving tax exemption to import such goods. 25

\section{Ambriz}

14 The 1859 gala dinner incident was by no means the first confrontation between Flores and the British representatives in Luanda. In 1851, the Brazilian had already been expelled from Luanda due to British pressures on the grounds that he had ties to a slave ship aprehended two years earlier. ${ }^{26}$ This apprehension highlighted Flores participation in the then booming shipments of slaves to Cuba. After being informed of Flores involvement with the slave ship, Portuguese authorities initially rejected British pressures to arrest him, despite putting him under surveillance. ${ }^{27}$ Eventually, however, they ordered him to leave Luanda. ${ }^{28}$ According to British diplomats, Flores had left for Rio de Janeiro, leaving behind "only one of his clerks to wind up the business [in Luanda]». ${ }^{29}$

Instead of Brazil, however, the Brazilian relocated to Ambriz, a region only 150 miles away from Luanda, outside Portuguese control but deeply connected to the capital city of Angola. As British authorities reported, «Ambriz, which from being immediately beyond the Portuguese territory and at the same time so near this place afforded such ample facilities to the slave dealer that it might be considered the slave port of Luanda». ${ }^{30}$ In Ambriz, Flores became the representative for Joaquim da Fonseca Guimarães e Companhia, a slave trading firm from Rio that organized shipments of slaves to Cuba. This firm was only one of several Brazilian firms that began investing in the slave trade to Cuba after the end of imports of slaves to Brazil in 1850. «The house of Manoel Pinto da Fonseca at Rio de Janeiro is also connected with that of Pedro Martinez at Havana». ${ }^{31}$

In 1857 alone, the British reported the capture of 16 slave vessels: «the whole of these vessels were engaged in the Cuban slave trade. Four of them had slaves on board at the time of the destruction, all of which had been shipped in the vicinity of the river Congo» ${ }^{32}$ Much of this trade occurred because slave dealers used the American flag to eschew British repression, taking advantage of the fact that the British could not legally apprehend American vessels because they did not have an anti-slave trade to Britain. As early as 1850, governor of Angola Adrião Acácio da Silveira Pinto, the use of the American flag turned the combat against the slave trade more difficult than when slave ships used the Brazilian flag. ${ }^{33}$

17 This situation represented a serious impediment to ending the transatlantic slave trade. Through diplomatic treaties, Britain had forced several countries to allow British 
ships the right of search - a critical tool to suppress the slave trade. However, «the search of American vessels by British anti-slavery patrols remained unauthorized and the flag of the United States remained a safe choice for slavers of all nations» (HUZZEY 2012: chapter three; OLDFIELD 2013: chapter seven). The United States government was deeply suspicious about British abolitionism that was perceived by American slave holders as a direct threat to the economic viability and international standing of the United States. American's geopolitics in defense of slavery ranged from Cuba, where geographic proximity made British pressure against the slave trade particularly palpable, to more remote Brazil (KARP 2011: 322).

It is important to emphasize that American involvement in the slave trade went well beyond the use of the American flag by slave dealers. Indeed, at least some of the vessels used to transport slaves to Cuba belonged to American investors. The Glamosgan, for example, belonged to the New York resident J. S. Hobson, «a name well known in connection with slave trade enterprises on this coast, and was commanded by an American citizen name P. R. Stanhop». ${ }^{34}$ Another ship was named «the Reinder, belonging to the house of H. J. Ingalss of New York, which has been lately sold, as we hear, to that of Machado or Reis». ${ }^{35}$

Many of these vessels were built in the United States and sailed to Africa directly from American cities such as Boston, New York, and New Orleans. As stated by known a slave dealer, «the ship will be cheaper if bought in Baltimore and should sail under the American flag». ${ }^{36}$ In 1854, the Glamorgan "sailed from NY on the 6th October and landed her cargo in January partly in the Congo and partly in Ambriz». ${ }^{37}$ In 1861, the British reported that «a schooner of about 70 tons called the Gilpins Brion is reported to have sailed within the last year from the Congo with slaves directly to Cuba. This vessel was built in America and sent out here by a Boston firm to facilitate the operations of its agents engaged in licit commerce on this coast». ${ }^{38}$

Since at least the 1840s, slave dealers had been using American built vessels to transport slaves across the Atlantic. ${ }^{39}$ There is evidence, however, that the 1850 s witnessed the introduction of a new generation of smaller and faster American vessels in the slave trade. As British authorities pointed out, «when the trade was brisk and plenty of vessels coming over to carry the slaves away, the employment of these small crafts was, I believe, seldom heard of.$^{40}$ Later, however, authorities remarked that "these apprehensions [of slave vessels off the coast of Angola], though for a time abated, have led very generally to a new mode of doing business", much of which rested on the use of small vessels built in the United States. ${ }^{41}$ In 1850, for example, the Benguela-based Manoel Antonio Teixeira Barboza purchased a ship in New York to transport slaves from Benguela to Brazil. ${ }^{42}$

21 The use of American ships gave slave dealers a technological edge that significantly reduced the efficacy of the warships patrolling the African coast against the slave trade. According to the Portuguese, one third of the American built vessels were able to escape British cruises..$^{43}$ However, the evidence suggests that the number might have been much larger. In 1853, for example, the commander of American vessels cruising against the slave trade sent a letter to the US requesting that smaller vessels be sent to cruise along the Angolan coast. ${ }^{44}$ In 1854, they were said to be "far superior to those of that brig or probably of any cruisers on the coast» ${ }^{45}$ In 1857, the British described a ship captured in Ambriz as «a remarkably fine vessel of 350 tons measurement and capable of carrying a thousand slaves». ${ }^{46}$ 

different from general policy towards slave dealers. In 1856, for example, the Portuguese government had issued a decree ordering the expulsion of notorious slave dealers from Portuguese Africa. ${ }^{54}$ In 1859, José Mendes Afonso, the highest judge in Luanda, advocated the highest punishment short of capital punishment to individuals implicated in slave dealing. ${ }^{55}$ Nor did Flores' presence in Luanda reflect Portuguese immigration policy towards Brazilian nationals. In 1845, authorities established that Brazilians would not be allowed to enter Angola without permission from the governor of Angola. ${ }^{56}$

Yet, Luanda authorities not only warmly welcomed Flores into Luanda but also persistently defied British pressures to expel the Brazilian national from Angola. In 1853, Jackson and Gabriel wrote that «Governors of this province have severally declared themselves under the necessity of tolerating, because he was residing here under a special 
license from her most faithful majesty, and because no positive proof of his complicity in slave traffic had been adduced against him». ${ }^{57}$ Indeed, Governor José Rodrigues Coelho do Amaral would openly discard British antagonism towards Flores in 1859, attributing it dissatisfaction over Flores' support to the Portuguese military expedition that had taken control of Ambriz in 1855. ${ }^{58}$

How to explain Portuguese authorities' behavior? Portugal's willingness to antagonize the British, the world's major naval power, even as the British seized territories in West Africa and exercised military power elsewhere in the Atlantic, derived from the pivotal role that Flores played as an architect of policies to consolidate Portuguese influence in Ambriz and Cabinda, where the Brazilian had extensive contacts with African chiefs. In 1853, for example, authorities stated that they had «decided to accept the offer of Francisco Antonio Flores to travel to Ambriz due to his influence in this point and constant willingness to help me with this extremely important question»..$^{59}$

To fully appreciate Flores' role in advancing colonial policies, it is necessary to understand Portuguese concerns about Ambriz and Cabinda. Despite Portugal's claims of sovereignty rights, Portuguese influence in Ambriz was minimal, with the Portuguese particularly fearful about growing British presence in these regions. In fact, Ambriz had long been marked by international trade. By the early 1830s, for example, it was mostly dominated by «American and British ships», as well as Spanish and Brazilian ships. ${ }^{60}$ Recognizing the growing importance of Ambriz and Cabinda to the continuation of the then illegal slave trade, the Portuguese stated that «if these ports were not occupied, the decree of December 101836 would be evaded». ${ }^{61}$

According to Lisbon, Portuguese sovereignty in Ambriz and Cabinda had been granted by treaty between Portugal and Britain from 1817. As a result, Lisbon instructed Governor Noronha to occupy the «foz of the river Zaire» where a city named new Lisbon would be founded on the "well founded hope that it will grow in commerce, wealth, and population, making it deserving of this denomination». ${ }^{62}$ However, it soon became obvious that not only the Luanda administration lacked the military means to these enforce plans but that the growing trade between Luanda and Ambriz might threaten the flow of primary goods from the Angolan country to Luanda. ${ }^{63}$ In addition to depriving Luanda of duties over commercial activities, the latter channeled to Ambriz goods that otherwise would be taken to Luanda, thus affecting Angolan transition from the slave trade to legitimate commerce ${ }^{64} \mathrm{By}$ the end of the 1840 s, Luanda merchants sought to legalize trade relations with Ambriz, even offering to pay duties in advance so as to be allowed to trade in Ambriz. ${ }^{65}$

31 Crucially, the increasing number of foreign traders represented an open threat to Portuguese claimed sovereignty rights. «Three fortifications of as many nations are erected on the bluff above mentioned; they are American, English and Sardinian» (GILLILAND 2003: 144-145). In 1841, American merchants refused to pay duties to the Portuguese on the grounds that «Portugal did not have more rights than other nations [trading] in that place [Ambriz] and because they paid [duties] to the king of gentios, they owed nothing to the government of the province [of Angola]» ${ }^{66}$ Further complicating Portuguese projects to gain a firmer foothold there, the number of foreigners in Ambriz increased as shipments of slaves came to an end in Luanda. In 1845, for example, authorities admitted that it would be impossible build the fort without «grave commotions» with France, Britain, and the United States. ${ }^{67}$ 

treaties with African chiefs that prohibited shipments of slaves and gave British traders an edge in the development of «licit commerce». «If the treaties with the chiefs of Cabenda and Ambriz could be enforced by us, it would be of vast benefit, and more particularly with Ambriz» (MATSON 1848: 75). A traveler who visited Angola in the 1850s stated that «The country of Angola extends from the southern border of Congo to the northern border of Benguela», yet «England has disputed» it (THOMAS 1860). In fact, Britain never challenged Portuguese control over Luanda and Benguela. However, it certainly harbored open and not so opened reservations about Portuguese. In 1859, Portuguese authorities reported that «Edmond Gabriel is a decided adversary of the extension of our control to the north» of Ambriz. ${ }^{68}$

African rulers so as to decrease the perils of foreign presence. In 1839, Lisbon specifically instructed recently appointed Governor Noronha: «it is necessary to strengthen ties with the prince and with the Mangobo Grande, who speaks English. In Cabinda [it would be necessary to establish ties], with the Mafuca Franque, who has been to Nantes, and who is already very friendly with the Portuguese». ${ }^{69}$ It is important to point out that Franque had «received a good education in the Brazils and has been for many years a notorious slave dealer» and would become particularly close of Franque. ${ }^{70}$

The relationship with the Franque family became an essential piece of Portuguese diplomacy with African chiefs in Cabinda. In 1853, for example, Governor Amaral stated: «I have tried all means to convince them [to support Portuguese rights over Ambriz and Cabinda], adopting all measures to provide for their wellbeing, and offering titles, hábitos and any other gift». ${ }^{71}$ Two years later, the governor wrote to Franque to say: «we trust God that it is not late to once and for all settle Portuguese sovereignty over Cabinda». Governor Amaral then went on to ensure the African ruler that «the services that you might conduct, as well as those who you have already conducted, will be duly rewarded with the generosity with which that her majesty treats her loyal subjects». ${ }^{72}$

It is important to emphasize that this diplomacy took place in a context of intense suspicion against British intents. In 1856, for example, rumors circulated in Luanda that the "British had educated in Santa Helena some Cabindas who had been released of a slave vessel» and planned to use them to foster a pro-British revolt. ${ }^{73}$ In response, the Luanda administration dispatched a warship to consult with Francisco Franque and Manoel Puna and «obtain intelligence that could be useful in this regard». ${ }^{74}$

Portuguese diplomacy towards African had gained momentum in 1853, when Luanda authorities received news that British warship Athol had disembarked troops «in Cabinda and taken control of that place, hoisting the British flag and removing the Portuguese flag»..$^{75}$ According to Portuguese reports, the British had gone to "the house of the Mambuco and invited him to drink rum, which he accepted, drinking something that he made him intoxicated». Afterwards, the British had made the Cabinda ruler sign a document giving the British territorial rights over Cabinda. ${ }^{76}$ In a letter to Luanda, Franque said: «what the government of her majesty needs to do as soon as possible is to deploy a military detachment and build [here]». ${ }^{77}$ Most importantly, because he had known Franque personally since the beginning of his investments in Cabinda in the late 1840s, Flores played a crucial role in this diplomacy. Significantly, it was through Flores that Franque would request the deployment of Portuguese troops to Cabinda so that a possible British intrusion could be avoided and Portuguese sovereignty could be consolidated. ${ }^{78}$ 


\section{Portuguese occupation of Ambriz}

British and American trade there. In 1856, British diplomats reported that «the invoice value of the British imports at that port during the year 1856 amounted to L25.913.00, and a considerable quantity of goods has also been imported there for lawful trade in the same period under the American flag». ${ }^{86}$ In the wake of the Portuguese expedition to Ambriz, however, British merchants petitioned the Portuguese government for financial compensations for their losses. ${ }^{87}$ Indeed, financial impact on British business was such that British authorities stated that the occupation would only be recognized if «the interest of the British merchants especially those already established at Ambriz shall be secured». ${ }^{88}$

41 To continue trading, many American and British moved to "a place called Kinsembo, about three miles north of the river Loje, which is rapidly absorbing the whole commerce of the former place [Ambriz]». However, the Luanda administration acted to counter this strategy by deploying Flores' trading house, which would offer African traders better prices than the British and Americans were willing to pay for ivory and other African products. According to the British, Flores' «agent here [Ambriz] has established a factory at a short distance from those mines where, with the strenuous support and patronage of this government, he succeeded in cutting off a considerable portion of the product [ivory] from the interior to the great detriment and injury of the [British and American] trade at Kinsembo». ${ }^{89}$ 
In 1857, a Portuguese mission registered 19 factories along the coast of Ambriz and Congo River: 12 were Portuguese, two were American, three were British, one was French and one was Spanish. Most of these factories (13) were located in Porto da Lenha, while two factories were located in Ambrizete, one was in Cabinda, two in Chimbica and one in Mangue Grande..$^{90}$ To appease the British, the Portuguese extended to them and the Americas the same fiscal regime used to collect import and export duties from Portuguese ships. However, there is no question that the expedition had achieved its commercial and geopolitical objective by bolstering Portuguese trade while undercutting foreign trade in Ambriz.

\section{Beyond Ambriz}

43 The Ambriz occupation was part of a larger project to extend Portuguese influence beyond Ambriz, with Flores as a key figure helping the Luanda administration to devise and execute such policies. As Flores pointed out, «the ponto limite, it seems to me, should be Molembo, where a fort should also be built». ${ }^{91}$ It led to the development of far more assertive policies towards regions neighboring Angola, particularly the king of Congo. In 1858, for example, the Luanda administration sent three envoys (Zacarias da Silva Cruz e Father José Maria de Moraes Gavião and Father José Agostinho Ferreira) to Congo on a political and diplomatic mission meant to influence the election of the new king of Congo. ${ }^{22}$

44 Significantly, the funds that allowed the three representatives to undertake their trip was provided by Francisco Antonio Flores's trading house. ${ }^{93}$ According to Luanda authorities, «we will slowly proceed to the absolute dominium if the circumstances [the election of Catende] are favorable». If not, «we will have to consider our resources in terms of protecting what we already have there, or become aggressive in his own territory. This would not be easy in the present circumstances». ${ }^{94}$ However, the succession process degenerated into a crisis pitting Catende against Dongo. While considering a military expedition to Congo, the Luanda administration stated that Catende and his followers could supply «an indigenous force sufficient to operate with ours» and then march «towards that city [Mbanza Congo]».95

45 To curb this revolt, the Portuguese sent a force that killed forty of Dongo's followers and occupied Mbanza Congo in 1860. According to official accounts, "Africans battled with great resolution but succumbed to the value of our soldiers». In fact, the Portuguese won due to the combination of artillery power and the deployment of cavalry forces. ${ }^{96}$ After this expedition, Luanda authorities declared that the Portuguese flight was flutuando in the Congo, "where our troops had been able to expel the faction of the rebel prince and destroy their banzas and settlements». Portuguese soldiers would remain in Congo to protect the new king of Congo. If they withdrew, they argued, the ruler could overthrow and «we would come under the threat of losing Bembe, Encoje, and even Ambriz», as well as positions in Congo and Banza-a-Puto. ${ }^{97}$

More importantly, Flores played a critical role in the expedition to Mbanza, like he had done in all other diplomatic and military maneuvering by the Luanda administration in the previous decade. The Brazilian merchant even participated in sessions of the Junta of Governo of Angola to discuss the occupation of Bembe, joining recently appointed governor of Angola José Rodrigues Coelho do Amaral and other authorities. ${ }^{98}$ Together with Garrido, Flores accompanied the disembark of troops in Ambriz and, as Luanda 
authorities admitted, demonstrated more knowledge about the region than colonial administrators in charge of Ambriz. According to Amaral, «the [military] expedition left for Ambriz thanks to the good work of Francisco Antonio Flores, always tireless, and his partner Augusto Garrido, who had given all support and co-shared decisions by the government».99

\section{Conclusion}

The relationship between British diplomat George Jackson and Brazilian slave dealer Francisco Antonio Flores sheds critical light on imperial disputes in Angola and neighboring regions in the last phase of the slave trade. Firstly, Flores' trajectory provides glimpses into the expanding transatlantic networks of the Angolan slave trade. Secondly, it illustrates rivalries over the delineation of sovereignty rights in Angola, since Flores seems to have earned British hostility not only because of his slave trade activities but also because he had been one of the architects of colonial policies towards Ambriz. Thirdly, the incident is also significant because of the ambiguous role that Flores played in the promotion of the legal activities that replaced the slave trade in Angola. My analysis demonstrates that colonial settings were incubators of colonial policies, which were devised not only in Lisbon but could also be born or enhanced on the ground by colonial administrators and local elites.

\section{BIBLIOGRAPHY}

ANNAES, 1867, Annaes do Conselho Ultramarino. Lisboa, Imprensa Nacional.

BENTON Lauren, 2011, «Abolition and Imperial Law, 1790-1820», The Journal of Imperial and Commonwealth History, vol. 39, n. 9 .

BURTON Richard, 1876, Two trips to Gorilla Land and the Cataracts of the Congo. London, Sampson Low, Marston, Low, and Searle.

GILLILAND Herbert, 2003, Voyage to a Thousand cares: Master's Mate Lawrence with the African Squadron, 1844-1846. Annapolis, Naval Institute Press.

HUZZEY Richard, 2012, Freedom burning: Anti-slavery and empire in victorian Britain. Ithaca e Londres, Cornell University Press.

JACKSON Lady (ed.), 1872, The Diaries and Letters of Sir George Jackson K. C. H. Londres, Richard Bentley and son.

KARASCH Mary C., 1967, The Brazilian slaves and the illegal slave trade, 1836-1851. Madison, University of Wisconsin (M.A., Wisconsin).

KARP Matthew, 2011, «Slavery and american sea power: The navalist impulse in the antebellum south», The Journal of Southern History, vol. LXXVII, n. 2, pp. 283-324.

MATSON Henry, 1848, Remarks on the Slave Trade and African Squadron. London, James Ridgway. 
OLDFIELD John, 2013, Transatlantic abolitionism in the Age of Revolution: An international history of anti-slavery, c. 1787-1820. New York, Cambridge University Press.

THOMAS Charles W., 1860, Adventures and observations on the West Coast of Africa, and its islands. Historical and descriptive sketches of Madeira, Canary, Biafra, and Cap Verd islands; their climates, inhabitants, and productions. Account of places, peoples, customs, trade, missionary operations, etc., etc., on that part of the African Coast lying between Tangier, Morocco, and Benguela, by Rev. Charles W. Thomas, with illustrations from original drawings. New York, Derby \& Jackson.

\section{NOTES}

1. "Ofício do Governador de Angola» on September 26, 1859, Arquivo Histórico Ultramarino (AHU), segunda secção de Angola, pasta 25 (3).

2. Translation of letter by Antonio Augusto Teixeira de Vasconcellos, on May 20, 1853, British National Archives (BNA), FO 84, 902, fls. 480-484; Dispatch by Jackson on April 13, 1853, FO 84, 902, fls. 469-471.

3. Dispatch by Edmond Gabriel on December 22, 1846, BNA, FO 84, 627, fls. 255--256.

4. Dispatch by Edmund Gabriel on November 8, 1845, BNA, FO 84, 569, fls. 283--287.

5. «Relatório Confidencial sobre os Negócios de Cabinda e Ambriz» on December 13, 1853, Sociedade de Geographia de Lisboa (SGL), reservados 2, maço 4, doc. 80 (1).

6. «Relatório Confidencial sobre os Negócios de Cabinda e Ambriz» on December 13, 1853, SGL, reservados 2, maço 4, doc. 80 (1).

7. «Ofício do Governador de Angola» on September 26, 1859, AHU, segunda secção de Angola, pasta 25 (3).

8. "Acta da Sessão do Conselho de Governo» on October 27, 1843, Arquivo Histórico de Angola (AHA), cód. 2856, fls. 45-45v. At the time, Flores did not own property in Luanda and could not sign the document. See «Sessão do Conselho de Governo» on December 30, 1843, AHA, cód. 2856, fls. 46-46v.

9. «Ofício do Vice-Cônsul Português no Rio de Janeiro» on November 14, 1846, AHA, cx. 1479.

10. Auto de declaração de José Alexandre Farrujo à polícia da corte do Rio de Janeiro em 11 de maio de 1855, Arquivo Nacional do Rio de Janeiro (ANRJ), IJ6 472. «Ofício do Governador de Angola» on September 26, 1859, AHU, segunda secção de Angola, pasta 25 (3).

11. AHA, cód. 167, fl. 14.

12. «Passaporte de Francisco Antonio Flores» on November 18, 1846, AHA, cód. 2514, fls. 18v.-19.

13. «Registo de concessão de passaportes» on September 7, 1849, AHA, cx. 1736, fl. 18.

14. «Ofício do Juiz de Direito de Luanda» on January 20, 1842, AHU, segunda seção de Angola, pastas 5 A e 5 B.

15. «Ofício do Governador de Angola» on July 11, 1842, AHU, segunda seção de Angola, pastas 5 A e 5 B.

16. «Carta de Arsenio» on May 10, 1843, AHU, segunda seção de Angola, pasta 6 A.

17. «Ofício do Juiz de Direito de Luanda» on July 7, 1843, AHU, segunda secção de Angola, pasta 6

A.

18. The donation was used to hospital equipments. See «Ofício do Secretário Geral do Governo de Angola» on January 20, 1855, AHA, cód. 179, fl. 118.

19. «Ofício do Chefe da Tropa de Guarnição de Luanda» on July 15, 1856, BOGGPA, n.o 563, p. 11.

20. «Ofício do Governador de Angola» on July 17, 1857, AHA, cód. 225, fls. 311-313.

21. «Ofício do Governador de Angola» on July 24, 1858, AHU, segunda secção de Angola, pasta 24

(1).

22. «Ofício do Governador de Benguela» on November 18, 1858, AHA, cód. 457, fl. 21. 
23. «Despachos 460, 461 e 462», on March 26, 1856, AHA, cód. 2619, fl. 72.

24. «Ofício do Governador de Angola» on February 22, 1858, AHA, cód. 114, fl. 162v.

25. «Ofício do Secretário Geral do Governo de Angola» on March 19, 1856, AHA, cód. 113, fls. 151v.

26. «Ofício do Governador de Angola» on January 17, 1850, AHU, segunda secção de Angola, pasta $16 \mathrm{~A}$.

27. «Ofício do Governador de Angola» on January 17, 1850, AHU, segunda secção de Angola, pasta $16 \mathrm{~A}$.

28. «Portaria do Ministério da Marinha e Ultramar» on September 9, 1850, AHA, cód. 263, fl. 172v.

29. Dispatch by Brand on January 13, 1851, FO 84, 841, fls. 169-172.

30. Dispatch by Brand on January 13, 1851, FO 84, 841, fls. 169-172.

31. Annual report on the slave trade by Gabriel and Jackson on February 5, 1850, FO 84, 793, fls. 91-108.

32. Report on the state of the slave trade by Gabriel on February 25, 1858, FO 84, 1043, fls. 121-150.

33. «Ofício do Governador de Angola» on March 28, 1850, AHA, cód. 19, fls. 29v.-30.

34. Dispatch by Gabriel on January 15, 1859, FO 84, 1075, fls. 22-25.

35. Dispatch by Gabriel and Jackson on October 23, 1856, FO 84, 985, fls. 393-393v.

36. «Carta de Guilherme Jose da Silva Correa» on April 21, 1855, AHU, segunda secção de Angola, Pasta $22 \mathrm{~A}$.

37. Dispatch by Gabriel and Jackson on March 28, 1854, FO 84, 932, fls. 83-87.

38. Dispatch by Gabriel and Henry Huntley on October 10, 1861, FO 84, 1133, fls. 21-33v.

39. «Ofício do Consul Brasileiro em New Orleans» on May 16, 1840, Arquivo do Itamarati, 258/3/4.

40. Dispatch by Brand on January 13, 1851, FO 84, 841, fls. 169-172.

41. Report on the Slave Trade by Jackson and Gabriel on February 21, 1854, FO 84, 932, fls. 45-53.

42. «Ofício do Secretário Geral do Governor de Angola» on September 3, 1850, AHA, cód. 511, fls. $29 \mathrm{v} .-30$.

43. «Ofício do Governador de Angola» on December 17, 1857, AHA, cód. 68, fls 74--75.

44. Dispatch by Gabriel and Jackson on November 19, 1853, FO 84, 902, fls. 355-360.

45. Dispatch by Gabriel and Jackson on March 28, 1854, FO 84, 932, fls. 83-87.

46. Dispatch by Gabriel on September 18, 1857, FO 83, 1013, fls. 374-376.

47. Dispatch by Gabriel and Jackson on December 26, 1853, FO 84, 902, fls. 390--393.

48. «Ofício do Governador Interino Antonio Ricardo Graça» on March 10, 1853, AHA, cód. 21, fls. $13-13 \mathrm{v}$.

49. Dispatch by Gabriel and Jackson on September 10, 1853, FO 84, 902, fls. 149--160.

50. Draft of Dispatch from London to Packenham in Lisbon on May 19, 1852, FO 84, 875, fls. $22-23 \mathrm{v}$.

51. «Depoimento de Vicente Daniel Cramtich» on February 4, 1856, AHA, cx. 1282.

52. «Carta de George Jackson» on July 26, 1856, AHU, segunda secção de Angola, pasta 22 A.

53. Dispatch by Jackson on May 23, 1853, FO 84, 902, fls. 473-478v.

54. Draft of letter to the British commissioners in Luanda on November 5, 1856, FO 84, 985, fls. 52-52v.

55. Dispatch by Edmond Gabriel on February 23, 1859, FO 84, 1075, fls. 35-45.

56. «Ofício do Secretário de Governo João de Roboredo» on November 14, 1845, AHA, cód. 104, fl. 65.

57. George Jackson \& Edmund Gabriel on April 11, 1853, in The Sessional Papers (London: The House of Lords, 1854).

58. «Ofício do Governador de Angola» on April 13, 1860, AHA, cód. 69, fls. 64v.-65v.

59. «Relatório confidencial sobre os negócios de Cabinda e Ambriz» on December 13, 1853, SGL, reservados 2, maço 4, doc. 80 (1). 
60. «Ofício do Governador de Angola» on December 14, 1830, AHA, cód. 12, fls. 59--61; «Ofício para o Governador de Angola» on August 2, 1831, AHA, cód. 12, fl. 83.

61. «Instruções Reservadas» on November 4, 1838, AHA, cód. 259, fls. 214-222v.

62. «Instruções Reservadas» on November 4, 1838, AHA, cód. 259, fls. 214-222v.

63. «Ofício do Governador de Angola» on January 17, 1841, AHA, cód. 15, fls. 26-26v.

64. «Portaria do Ministério da Marinha e Negócios do Ultramar» on August 24, 1846, AHA, cód. 262, fl. 1.

65. «Acta da Sessão do Conselho de Governo» on June 26, 1847, AHA, cód. 2856, fls. 93-96.

66. «Ofício do Governador de Angola» on January 17, 1841, AHA, cód. 15, fls. 25-25v.

67. «Ofício do Governador de Angola» on Augus 31, 1845, AHA, cód. 16, fls. 125v.-126.

68. «Ofício do Governor of Angola» on June 27, 1859, AHA, cód. 23, fls. 214-216.

69. «Portaria do Ministro da Marinha e Ultramar» on July 2, 1840, AHA, cód. 259, fls. 174v.-174.

70. Dispatch by Brand on March 16, 1853, FO 84, 909, fls. 260-265.

71. «Relatório confidencial sobre os negócios de Cabinda e Ambriz» on December 13, 1853, SGL, reservados 2, maço 4, doc. 80 (1).

72. «Ofício do Governador de Angola» on April 7, 1855, AHA, cód. 248, fls. 9-10.

73. «Ofício confidencial do Governador do Distrito de Ambriz» on November 26, 1856, AHU, papéis de Sá da Bandeira, maço 825.

74. «Ofício do Comandante da Estação Naval Portuguesa» on November 18, 1856, AHU, segunda secção de Angola, pasta 22 A.

75. «Relatório confidencial sobre os negócios de Cabinda e Ambriz» on December 13, 1853, SGL, reservados 2, maço 4, doc. 80 (1).

76. «Carta do Marquês do Lavradio» on September 17, 1853, FO 84, 909, fls. 120-139.

77. «Carta de Francisco Franque» on November 1, 1853, SGL, reservados 2, maço 4, doc. 80 (6).

78. «Carta de Francisco Franque» on November 1, 1853, SGL, reservados 2, maço 4, doc. 80 (6).

79. «Ofício do Governador de Angola» on July 26, 1856, AHA, cód. 248, fl. 29.

80. «Ofício do Secretário Geral de Angola» on September 9, 1856, AHA, cód. 857, fls. 6-6v.

81. «Ofício do Comandante João Maximo de Rodovalho» on August 12, 1856, AHU, segunda seção de Angola, pasta $22 \mathrm{~A}$.

82. «Ofício do Secretário Geral do Governo de Angola» on May 26, 1855, AHA, cód. 179, fl. 219.

83. «Carta de Francisco Antonio Flores» on April 30, 1856, AHU, papéis de Sá da Bandeira, maço 827.

84. «Carta de Francisco de Salles Ferreira» on August 17, 1856, AHU, segunda secção de Angola, pasta $22 \mathrm{~A}$.

85. «Carta de Augusto Garrido» on December 27, 1856, AHU, segunda secção de Angola, pasta 23 (1).

86. Report on the slave trade by Gabriel on February 11, 1857, FO 83, 1013, fls. 130--150.

87. «Ofício do Governador do Ambriz» on August 21, 1855, AHU, segunda secção de Angola, pasta $23(1)$.

88. «Carta do Comandante do Esquadrão Britânico» on August 4, 1856, AHU, segunda secção de Angola, pasta $22 \mathrm{~A}$.

89. Report on the state of the slave trade by Gabriel on February 25, 1858, FO 84, 1043, fls. 121-150.

90. «Registo de Feitorias pelo Brigue Vila Flor» between April 25 and June 7, 1857, AHU, segunda secção de Angola, pasta 23 (3).

91. «Carta de Francisco Antonio Flores» on April 30, 1856, AHU, papéis de Sá da Bandeira, maço 827.

92. «Instruções do Governador de Angola» on September 10, 1858, AHU, segunda secção de Angola, pasta 24 (2). 
93. «Instruções do Governador de Angola» on September 10, 1858, AHU, segunda secção de Angola, pasta 24 (2).

94. «Ofício do Governador de Angola» on November 23, 1858, AHU, segunda secção de Angola, pasta 24 (2).

95. «Ofício do Secretário Geral de Governo» on December 9, 1858, AHA, cód. 115, fls. 46-46v.

96. «Ofício de Jose Baptista de Andrade» on September 16, 1860, AHU, segunda secção de Angola, pasta 27.

97. «Ofício do Governo de Angola» on October 31, 1860, AHU, segunda secção de Angola, pasta 27.

98. «Acta da Sessão do Conselho de Governo de Angola» on July 30, 1860, AHU, segunda secção de Angola, pasta 27.

99. «Ofício do Governo de Angola» on October 31, 1860, AHU, segunda secção de Angola, pasta 27.

\section{ABSTRACTS}

This article deals with the conquest of Ambriz in the 1850s. It places it in the broader conquest of the end of the transatlantic slave trade in Angola and Ambriz, as well as imperial in the context of fierce disputes that pitted the Portuguese against the British in the region. The article argues that Portuguese colonial expansion towards Ambriz was part of broader plans to strengthen colonial ties to Angola that began with the end of the transatlantic slave trade. To understand the conquest of Ambriz, the article reconstructs the relationship between the Brazilian investor Francisco Antonio Flores and the British diplomat George Jackson.

Este artigo trata da conquista de Ambriz na década de 1850. Esta é colocada no panorama mais amplo do fim do tráfico transatlântico de escravos em Angola e Ambriz, bem como no contexto de acirradas disputas imperiais que opunham os portugueses aos britânicos na região. 0 artigo argumenta que a expansão colonial portuguesa em direcção a Ambriz fazia parte de planos mais amplos para fortalecer os laços coloniais com Angola, que começou com o fim do tráfico transatlântico de escravos. Para compreender a conquista de Ambriz, o artigo reconstrói a relação entre o investidor brasileiro Francisco Antônio Flores e o diplomata britânico George Jackson.

\section{INDEX}

Keywords: colonial expansion, slave trade, abolitionism

Palavras-chave: expansão Colonial, tráfico de escravos, abolicionismo

\section{AUTHOR}

\section{ROQUINALDO FERREIRA}

roquinaldo_ferreira@brown.edu

Vasco da Gama associate professor in History/Portuguese and Brazilien Studies na University of Brown, nos Estados Unidos da América. 
É doutor em História de África pela Universidade da Califórnia, Los Angeles, nos Estados Unidos da América. A sua tese de doutoramento, defendida em 2003, intitula-se Transforming Atlantic slaving: Trade, warfare and territorial control in Angola, 1650-1800 e foi preparada sob orientação do Prof. Dr. Edward Alpers. Nascido na cidade de Salvador, Bahia, República Federativa do Brasil, em 28 de Novembro de 1967, é licenciado em História (1992) e mestre em História Social (1996) pela Universidade Federal do Rio de Janeiro (UFRJ). No período de 1993 a 1997, foi pesquisador assistente no Centro de Estudos Afro-Asiáticos da Universidade Cândido Mendes no Rio de Janeiro; entre 2000 e 2002, foi pesquisador assistente na Hull University, na Inglaterra; em 2005, foi professor visitante na Universidade Federal Fluminense (UFF), em Niterói, Brasil; de 2005 a 2010, foi assistent professor of African and African American History, na University of Virginia e a partir de 2011, foi associate professor of African and African American History nessa mesma instituição universitária. Actualmente, é Vasco da Gama associate professor in History/Portuguese and Brazilian Studies na University of Brown, nos Estados Unidos da América (EUA). Além de artigos em revistas especializadas e capítulos de livros, é autor de Crosscultural Exchange un the Atlantic World: Angola and Brazil during the era of the slave trade (New York, Cambridge University Press, 2012) e de Dos sertões ao Atlântico. Tráfico ilegal de escravos e comércio lícito em Angola, 1830-1860 (Luanda, Kilombelombe, 2012). Tem em preparação a obra Pathways to colonialismo: abolitionism, territorial sovereignty, and unfree labor in Angola (ca. 1830-ca. 1860s). Anteriormente publicou neste mesmo órgão as conferências seguintes: «Slave flights and runaway communities in Angola (17th-19th centuries», Mulemba - Revista Angolana de Ciências Sociais (Luanda), vol. III, n. 9 6, Novembro 2013, pp. 55-80; «Biography as a social history: Abolitionism, colonialism and racial ideology in an Atlantic-wide world», Mulemba Revista Angolana de Ciências Sociais (Luanda), vol. IV, n.ำ 7, Maio 2014, pp. 209-239; e «Abolicionismo versus colonialismo: Rupturas e continuidades em Angola (século XIX)», Mulemba - Revista Angolana de Ciências Sociais (Luanda), vol. IV, n.․ 8, Novembro 2014, pp. 101-126. 